\title{
20. Nourishing Terrain: An Afterword
}

\author{
Gillian Whitlock
}

Ego-histoire is an unlikely import into Australian Indigenous studies. At least so it seemed to me in Paris in December 2011 at the conference that became a prehistory to this collection of essays. I listened as a non-Indigenous Australian researcher, sharing a concern for ethical ways of living, researching and teaching in Aboriginal country, and wondered why it was that ego-histoire was so confronting, and so unfamiliar in its address to Indigenous Australian studies. A number of writers here reflect this uneasiness, and in Pierre Nora's essay 'Is "Ego-Histoire" Possible?' (translated here in the Appendix) we see why this is so. Nora highlights the features of the intellectual environment in France that led to ego-histoire: 'the return of the subject', the historiographical turn, and the new regime of historicity in France in the late-1970s and early-1980s. The transposition of each of these to Australian Indigenous studies now immediately unsettles the gendered, national and individualist presuppositions of the project-limits of the genre that remain unremarked in Nora's essay. As a 'bemused' Jane Haggis suggests, Nora's cool, encompassing, explanatory gaze and its singular unitary history of the nation is unsettled in contemporary Australian studies. Like a number of other writers here, Haggis turns to 'entanglement' to understand the relations between self and other, the history of the narrator and the narrated, that circulate in contemporary Australian autobiographical writing, a writing that draws the contact zone and the incommensurability of Indigenous and settler histories into thinking about the self and its professional conduct as a humanities scholar. There is, Gillian Cowlishaw argues, a messiness in thinking about 'us' and 'other'. In response, Cowlishaw turns to the diary as a genre that personalises the professional life, as do a number of other writers here (see, for example, Jan Idle's 'field notes', and Ros Poignant's journal). This self-reflexive form of writing breaks down the distinctions between 'research practice' and 'findings or data', and what emerges is an 'entanglement' of Indigenous and non-Indigenous worlds that is both personally felt and professionally practised. The diary grasps that intimate immersion of the self in other worlds, a destabilising and disorienting knowledge and experience of otherness that recurs in this 'provincialisation' of ego-histoire into postcolonial space and time. More generally, these essays practise forms of autobiographical writing that enable a performative sense of self,, a working through memory and recognition, and what Franca Tamisari calls 'a personal way of knowing others' that finds expression in the classroom as well as in research practice: a 'methodology of encounter', Jan Idle suggests, where observing 'self out of place becomes part of the project'. 
To some extent this style of academic memoir is familiar in contemporary life narrative. Feminism, postcolonialism, and critical race theory, among other methodologies, have fostered an introspective and autobiographical turn in academic writing internationally for some time now. In Australia this took a particular form late last century, and in association with a politics of reconciliation and 'the history wars' (Macintyre \& Clark 2003; Clendinnen 2000; Read 2000). This produced what David Carter called 'the conscience industry': a style of public intellectual activism energised by national issues concerning land rights and native title, the Apology, frontier violence, child removal and genocide (Carter 2004, p. 17). A particular style of autobiographical narrative appeared: memoirs, essays and histories "exercising forms of "interiority" or "ethical self-reflection"' and an intense focus on issues of national conscience and civic virtue (Carter 2004, p. 33). The ethical force of bearing witness and engaging with history through personal responsibility reappears in the turn to ego-histoire on occasion; for example, the coming into knowledge of whiteness as a racial identity that is conventionally unmarked or transparent recurs, and 'haunted' white memoir presents a relocation of self in relation to settler ancestors and a previously unacknowledged Indigenous presence. But different styles of 'Turning into a Gardiya' emerge in ego-histoire, and these accommodate Stephen Muecke's turn to metamorphosis, with its bracing critique of sentimentality and its 'respectful' reproduction of Paddy Roe's Kimberley English and its ground-breaking language of reciprocity and storytelling. Similarly, Barry Judd's remarks on the practical usefulness of critical theory to deliver useful and practical outcomes for the elders of Papunya reflect back on discourses of reconciliation and benevolence with a critical eye on various forms of hegemony in settler cultures.

For Nora, ego-histoire was about the nation, and citizenship. Here it takes a very different turn. It is, as Oliver Haag suggests, a project inspired by a transnational approach to Indigenous studies. Recently, Graham Huggan has written critically of the assumption that Australian literary, historical and cultural studies represent a collective national project. Huggan's idea of work in the Australian humanities is global: its geographical and cultural horizons are expansive, and it is 'accountable to the wider world' (Huggan 2008, p. 13). There has been an implicit assumption, Huggan argues, that Australian literature and history is still primarily a matter to be debated among Australians: 'while it may not be strictly necessary to be Australian to write Australian literature, it certainly helps if one wants to do Australian literary criticism' (Huggan 2008, p. 145). Is this one reason why ego-histoire seems so strange as it draws together a new transnational community of scholars? The American critic Wai Chee Dimock remarks that literary studies conducted as citizenship studies is reflex action for many of us, for the national literature is a doxa: 'All the more reason, then, to bracket it, to experiment with other groupings less automatic and more 
generative of knowledge, if only because of the methodological self-awareness it requires.' (Dimock 2006, p. 226) This draws attention to the different jurisdictions of texts beyond or below the horizon of the nation.

This is exactly what ego-histoire does. It puts Australian texts and contexts in transit, into new expansive and transnational networks; it moves from Paris to Papunya, Mullimbimbi to Venice. I am using 'transit' here in the terms suggested by Jodi Byrd's The Transit of Empire, which envisages Indigenous critical practice as particularly open to the possibilities of comparative studies. Indigenous literature, she suggests, moves as an active presence, 'in multiple synchronic formulations' (Byrd 2011, p. xvii). Byrd acknowledges that transit is a provocative association, more commonly suited to diaspora studies than work on Indigeneity, but she means to emphasise how Indigeneity troubles sovereignty and citizenship, most particularly that of the nation, both close to home and further abroad. For Byrd, like other critics concerned with Indigenous critical theory (such as Povinelli and Moreton-Robinson), the nation invites disaggregation. The limited and provisional kinds of citizenship and belonging that become available to indigenous people in and through the nation, and the always troubled 'management' of Indigeneity by the settler state invites alternative concepts of sovereignty and belonging. Outside country, the transits of Indigenous writing trouble the thresholds of sovereignty and citizenship within Australia and offshore. 'Country' is a key word of Aboriginal English, used all over Aboriginal Australia to name the place where a person belongs in terms of kinship, which imposes mutual responsibilities of caring and keeping upon land and people (Bonyhady \& Griffiths 2002 p. 2). ${ }^{1}$ In the terms of Melissa Lucashenko's 'earthspeaking', 'known country' is a sacred ground of Indigenous language, culture, nurture, sanctuary, responsibility and safety; every landscape of this country has its Dreaming Law (Lucashenko 2006, p. 28). ${ }^{2}$ The anthropologist Deborah Bird Rose describes Country as 'nourishing terrain':

Country in Aboriginal English is not only a common noun but also a proper noun. People talk about country in the same way that they would talk about a person: they speak to country, sing to country, visit country, worry about country, feel sorry for country, and long for country. People say that country knows, hears, smells, takes notice, takes care, is sorry or happy. Country is not a generalised or undifferentiated type of place, such as one might indicate with terms

\footnotetext{
1 'Country' in this sense is an Australian Indigenous term that refers to what is elsewhere understood as the distinctive claims to land, kinship communities, native languages, and traditional practices that are foundational to first nations' identity and belonging.

2 'Known indigenous country is healing, nurture, sanctuary, responsibility and safety. Unknown country is frightening, inhabited by dangerous spirits, liable to violent defence by its true people. Yet in an indigenous sensibility, there is (or was prior to the massacres and removals) no wilderness, no barren land and no dead heart. The land is not cursed and nor are its human inhabitants. Resurrection is not required where there has been no Fall' (Lucashenko 2006, p. 28).
} 
like 'spending a day in the country' or 'going up the country'. Rather, country is a living entity with a yesterday, today and tomorrow, with a consciousness, and a will toward life. Because of this richness, country is home, and peace; nourishment for body, mind and spirit; heart's ease (Bird Rose 1997, p. 7).

Bird Rose astutely grasps the difference of 'country' in Indigenous epistemologies and the 'country' we find in Raymond Williams' Keywords, a definition shaped by the history and culture of western modernity (Williams 1985). Interpretations of country as living presence with its own set of memories permeate contemporary Indigenous writing and criticism. Country is nourishing terrain of Indigenous sovereignty. In these essays Indigenous land and people are recalled with an affective force that affirms country as a shared heritage of belonging: in Philip Morrissey's 'Tales of Mystery and Imagination from the Tweed River', for example, which translates country in terms of a hybridised community of Aboriginal and South Sea Islanders that imaginatively reaches across to the Kimberleys, as well as the storytelling of Paddy Roe and Stephen Muecke.

The turn to ego-histoire opens a new space for thinking about the transits of Indigenous literature, art and film in Europe, and it suggests how European Australian studies emerges as a distinctive presence. Transits such as this raise questions about what kinds of agency become available to Indigenous texts in 'foreign' country, and it opens up ways of thinking about the nation itself as 'foreign' terrain. These new affiliations include connections between Indigenous and European histories, as ego-histoire turns to traumatic memories that circulate in the wake of its civil wars, genocides, partitions and terrors, and explores how these connect to Indigenous archives of memory. We see this, for example, in Oliver Haag's essay on Romany Europe and Indigenous Australia. Or, very differently, in the transnational imaginary that emerges in Philip Morrissey's invocation of nostalgic memory connecting the Tweed River to the agrarian Wessex of Thomas Hardy. This voice of 'Home Talk' that responds to ego-histoire can experiment with embodiment and voice in an expansive transnational world, such as the conversation between May-Britt Öhman and Frances Wyld, which translates 'discipline' not in terms of conventional institutional practice but as Indigenous embodied and remembered language and experiences. Like Jeanine Leane, for Öhman and Wyld, ego-histoire is an invitation to depart from scholarly languages that cannot give voice to Indigenous embodiment and experience; 'this is a story', says Leane, and for her, like Morrissey, ego-histoire becomes an opportunity to write in an expansive transnational frame 'in the first person', a story that incorporates the canon of English literature and the history of ancient Rome as well as Australian literature. The Wiradjuri landscape and epistemology of Leane's storytelling refuses to be contained by the imaginary of the settler nation, and its generic Aboriginal subject. 
In this way, ego-histoire generates new filiations on different scales of citizenship and belonging, kindled by the agency of Indigenous culture, history and literature to reach outside country and beyond the nation. These are not merely amiable reflections of the work we do as citizens of the nation in immediate proximity to country, and tenuously reconciled with it. This is genuinely and interestingly a 'foreign' country, generative of new subjects and sovereignties. And so it is that ego-histoire brings us home other-wise, in a productive unsettlement of citizenship that calls into question our scholarly disciplines, and to think anew about what it means to practice them here, nourished by the terrain of Aboriginal country.

\section{References}

Bird Rose, D 2004, Reports from a Wild Country: Ethics for decolonisation, UNSW Press, Sydney.

Bird Rose, D 1997, Nourishing Terrains: Australian Aboriginal views of landscape and wilderness, Australian Heritage Commission, Canberra.

Bonyhady, T \& T Griffiths (eds) 2002, Words for Country: Landscape and language in Australia, UNSW Press, Sydney.

Byrd, J A 2011, The Transit of Empire: Indigenous critiques of colonialism, University of Minnesota Press, Minneapolis.

Byrd, J A \& M Rothberg 2011, 'Between Subalterneity and Indigeneity', Interventions, vol. 13, no. 1, pp. 1-12.

Carter, D (ed.) 2004, The Ideas Market, Melbourne University Press, Melbourne.

Clendinnen, I 2000, Tiger's Eye: A memoir, Text, Melbourne.

Dimock, W C 2006, 'Scales of Aggregation: Prenational, Subnational, Transnational', American Literary History, vol. 18, no. 2, pp. 219-228.

Huggan, G2008, Australian Literature:Postcolonialism, Racism, Transnationalism, Oxford University Press, Oxford.

Lucashenko, M 2006, 'Not Quite White in the Head', Manoa, vol. 18, no. 2, pp. 23-51.

Macintyre, S \& A Clark 2003, The History Wars, Melbourne University Press, Melbourne. 
Ngapartji Ngapartji, In Turn, In Turn: Ego-histoire, Europe and Indigenous Australia

Read, P 2000, Belonging: Australians, place and Aboriginal ownership, Cambridge University Press, Cambridge.

Whitlock, G 2004, 'Becoming Migloo', in D Carter (ed.), The Ideas Market, Melbourne University Press, Melbourne, pp. 236-258.

Williams, R 1985, Keywords: A vocabulary of culture and society, Oxford University Press, Oxford. 
This text taken from Ngapartji Ngpartji: In turn in turn:

Ego-histoire, Europe and Indigenous Australia

Edited by Vanessa Castejon, Anna Cole, Oliver Haag and Karen Hughes,

published 2014 by ANU Press, The Australian National University, Canberra, Australia. 